\title{
IMPLEMENTASI PENDAFTARAN HAK ATAS TANAH KOMUNAL DI DESA ADAT PAKRAMAN BUNGBUNGAN BALI
}

\author{
IMPLEMENTATION OF REGISTRATION OF COMMUNAL LAND RIGHTS IN PAKRAMAN \\ TRADITIONAL VILLAGE BUNGBUNGAN BALI
}

\section{Ni Putu Adnyani*, Imam Kuswahyono, Supriyadi \\ Program Studi Magister Kenotariatan \\ Universitas Brawijaya \\ Jalan MT. Hariyono 169, Malang 65145 Indonesia}

\section{INFO ARTIKEL}

\section{Riwayat Artikel:}

Diterima : 17 September 2019

Disetujui : 09 Juni 2020

\section{Keywords:}

communal land, pakraman

traditional village,

registration of land rights

\section{Kata Kunci:}

tanah komunal, desa adat pakraman, pendaftaran

hak atas tanah

\section{*) Korespondensi:}

E-mail: adnyani.kembar@gmail.com

\begin{abstract}
: this study aimed to analyze the application of the registration of communal land rights of indigenous and tribal peoples in the Pakraman Bungbungan Traditional Village, Jembrana Regency, as well as to explore issues that hampered registration of communal land rights and efforts made by the government to overcome these obstacles. The study method used an empirical legal study with a sociological juridical approach. From the study results, it was known that the registration of communal land rights in the Desa Adat Pakraman Bungbungan, Jembrana Regency, Bali Province was implemented through the Government's Strategic Program, namely the Complete Systematic Land Registration 2019. There were several obstacles experienced, one of them being the community's ignorance of the communal land registration process. The effort made by officials of the Jembrana District Land Office was to disseminate information to indigenous peoples regarding the way to register communal land.
\end{abstract}

\begin{abstract}
Abstrak: kajian ini bertujuan untuk menganalisis penerapan pendaftaran hak atas tanah komunal masyarakat hukum adat di Desa Adat Pakraman Bungbungan Kabupaten Jembrana, serta menelusuri hal-hal yang menghambat pendaftaran hak atas tanah komunal dan upaya yang dilakukan oleh pemerintah untuk mengatasi hambatan tersebut. Metode kajian digunakan adalah kajian hukum empiris dengan pendekatan yuridis sosiologis. Dari hasil kajian diketahui bahwa pendaftaran hak atas tanah komunal di Desa Adat Pakraman Bungbungan Kabupaten Jembrana Provinsi Bali diimplementasikan melalui Program Strategis Pemerintah yaitu Pendaftaran Tanah Sistematis Lengkap (PTSL) 2019. Ada beberapa hambatan yang dialami, salah satunya ketidaktahuan masyarakat tentang proses pendaftaran tanah komunal. Adapun upaya yang dilakukan oleh pejabat Kantor Pertanahan Kabupaten Jembrana ialah melakukan sosialisasi kepada masyarakat adat terkait cara pendaftaran tanah komunal.
\end{abstract}

\section{PENDAHULUAN}

Indonesia terdiri atas berbagai suku, agama, budaya dan bahasa yang menjadi kekuatan tersendiri dalam melaksanakan pembangunan di segala bidang, untuk kelestarian kekayaan atas keragaman tersebut, setiap pembangunan yang dilakukan oleh pemerintah juga harus memperhatikan hukum yang berlaku. Hal ini sejalan dengan amanat konstitusi sebagaimana Ketentuan Pasal 1 ayat (3) Undang-Undang Dasar Negara Republik Indonesia Tahun 1945 yang menjelaskan bahwa Indonesia merupakan 
negara hukum. Maka dari itu, segala kebijakan yang akan dibuat dan dilakukan oleh pemerintah harus berdasar pada hukum yang berlaku.

Kebijakan-kebijakan terkait dengan pengelolaan sumber daya alam adalah hal penting yang perlu disikapi secara serius oleh pemerintah. Hal ini dikarenakan pengelolaan sumber daya alam berkenaan dengan kebutuhan utama seluruh masyarakat Indonesia. Undang-Undang Dasar Negara Republik Indonesia Tahun 1945 Pasal 33 ayat (1) telah menegaskan bahwa "Bumi, air, dan kekayaan alam yang terkandung di dalamnya dikuasai oleh Negara dan dipergunakan untuk sebesar-besar kemakmuran rakyat". Salah satu obyek pengaturan sebagaimana yang disebutkan di dalam Pasal 33 ayat (3) tersebut adalah bumi yang terdiri atas permukaan bumi (tanah) dan tubuh bumi.

Penguasaan dan kepemilikan tanah seringkali menimbulkan konflik, baik konflik vertikal maupun konflik horizontal. Maka dari itu, perlu adanya kepastian hukum terhadap kepemilikan tanah bagi subyek hukum yang memiliki tanah (Muhammad, Agustian, \& Safultra, 2018). Dalam mewujudkan kepastian hukum terhadap kepemilikan tanah di Indonesia telah diatur dalam Pasal 19 ayat (1) Undang-Undang Nomor 5 Tahun 1960 tentang Peraturan Dasar Pokok-Pokok Agraria (selanjutnya ditulis UUPA) yang mengatur bahwa "Untuk menjamin kepastian hukum oleh Pemerintah diadakan pendaftaran tanah di seluruh wilayah Republik Indonesia menurut ketentuan-ketentuan yang diatur dengan Peraturan Pemerintah". Pendaftaran tanah memberikan dampak yang baik, antara lain: (a) adanya kepastian hukum hak atas tanah, (b) sistem layanan pendaftaran tanah yang bersih dan tertib, (c) terhindarnya konflik atau pertikaian akibat status sertifikat, (d) tercipta kepercayaan masyarakat terhadap Badan Pertanahan Nasional (Sinaga, 2014).

Dalam Pasal 1 ayat (1) Peraturan Pemerintah Nomor 24 Tahun 1997 menyebutkan bahwa pendaftaran tanah merupakan rangkaian. kegiatan yang dilakukan oleh pemerintah secara terus menerus, berkesinambungan, dan teratur meliputi pengumpulan, pengolahan, pembukuan dan penyajian, serta pemeliharaan data fisik dan data yuridis, dalam bentuk peta dan daftar mengenai bidang-bidang tanah dan satuan-satuan rumah susun termasuk pemberian surat tanda bukti haknya bagi bidang-bidang tanah yang sudah ada haknya dan hak milik atas satuan rumah susun serta hak-hak tertentu yang membebaninya. Dalam Pasal 3 huruf a dan Pasal 4 ayat (1) disebutkan bahwa salah satu tujuan dilaksanakan pendaftaran tanah adalah memberikan kepastian hukum dan perlindungan hukum kepada pemegang hak atas suatu bidang tanah, satuan rumah susun, dan hak-hak lain yang terdaftar agar dengan mudah dapat membuktikan dirinya sebagai pemegang hak yang bersangkutan dan untuk itu kepada pemegang yang bersangkutan diberikan sertifikat hak atas tanah.

Pasal 9 Peraturan Pemerintah Nomor 24 Tahun 1997 tentang Pendaftaran Tanah mengatur bahwa obyek pendaftaran tanah meliputi, (a) bidang-bidang tanah yang dipunyai dengan hak milik, hak guna usaha, hak guna bangunan dan hak pakai; (b) tanah hak pengelolaan; (c) tanah wakaf; (d) hak milik atas satuan rumah susun; (e) hak tanggungan; dan (f) tanah negara. Adanya Peraturan Menteri Agraria dan Tata Ruang/Kepala Badan Pertanahan Nasional Nomor 10 Tahun 2016 tentang Tata Cara Penetapan Hak Komunal Atas Tanah Masyarakat Hukum Adat dan Masyarakat yang Berada Dalam Kawasan Tertentu memberikan perluasan penafsiran tentang hak milik yang diatur dalam Pasal 9 Peraturan Pemerintah Nomor 24 Tahun 1997 tentang Pendaftaran Tanah.

Hak milik yang awalnya didefinisikan sebagai obyek tanah yang dimiliki oleh individu, saat ini dengan adanya peraturan menteri tersebut disebutkan bahwa hak milik dapat diberikan terhadap tanah yang dimiliki oleh suatu kelompok (komunal). Teori hak menyatakan bahwa di dalam hak terkandung unsur perlindungan, kepentingan, dan kehendak. Apabila seseorang memiliki sebidang tanah, maka hukum memberikan hak kepadanya dalam arti bahwa kepentingan orang itu mendapatkan perlindungan. Kehendak yang demikian itu identik dengan kewenangan yang ditimbulkan oleh hukum (Azzahra, 2019). Perlindungan itu selain ditujukan pada kepentingan orang tersebut juga ditujukan pada kehendaknya atas tanah itu.

Pada praktiknya, implementasi peraturan tentang pendaftaran tanah guna di Indonesia masih terdapat masalah. Salah satu permasalahan yang timbul adalah pendaftaran tanah bagi masyarakat hukum adat sebagaimana yang terdapat di 
Desa Pakraman Bungbungan Desa Yehembang Kecamatan Mendoyo Kabupaten Jembrana Provinsi Bali. Berdasarkan hasil pengamatan penulis yang dilakukan di Desa Pakraman, seluruh penduduk desa masih belum ada yang memiliki sertifikat hak atas tanah. Prinsip hukum adat dalam UUPA adalah perangkat hukum yang berdasarkan atas hukum adat, walaupun kedudukan, pengertian, dan ruang lingkup dari hukum adat yang dimaksudkan di sini berbeda dengan kedudukan, pengertian dan ruang lingkup hukum adat tradisional yang dikenal sebelumnya. Apabila UUPA juga memberikan kemungkinan terjadinya hak milik menurut ketentuan yang dahulunya dikenal dalam hukum adat yang berlaku di Indonesia, hal tersebut merupakan suatu kewajaran.

Adanya ketentuan di atas menimbulkan suatu penafsiran bahwa UUPA masih membuka peluang tanah adat dan tanah barat sehingga terdapat pula yang disebut hak milik adat dan hak milik barat (Sudantra, 2018). Hak milik yang terjadi karena hukum adat akan menimbulkan sesuatu hal yang disebut hukum adat, dan hak milik yang terjadi karena penetapan pemerintah atau penetapan undang-undang menimbulkan hak milik menurut undang-undang (Soedjono, 2008). Saat ini hak milik adat bukan hanya diakui eksistensinya berdasarkan hukum adat, negara telah menjamin kepastian hukumnya berdasarkan Peraturan Menteri Agraria dan Tata Ruang/Kepala Badan Pertanahan Nasional Nomor 10 Tahun 2016 tentang Tata Cara Penetapan Hak Komunal Atas Tanah Masyarakat Hukum Adat dan Masyarakat yang Berada Dalam Kawasan Tertentu yang disahkan pada tanggal 21 Maret 2016.

Sertifikat merupakan jaminan kepastian hukum bagi pemegang hak atas tanah. Hal ini sangat berkaitan dengan konteks penguasaan tanah adat dan/atau tanah ulayat. Negara telah merespon penguasaan tanah adat oleh masyarakat adat yang selama ini masih ada dan diakui keberadaannya dengan diterbitkan Peraturan Menteri Agraria dan Tata Ruang/Kepala Badan Pertanahan Nasional Nomor 10 Tahun 2016 tentang Tata Cara Penetapan Hak Komunal Atas Tanah Masyarakat Hukum Adat dan Masyarakat yang Berada Dalam Kawasan Tertentu maka lahirlah satu jenis sertifikat baru yang disebut dengan sertifikat hak komunal.
Keberadaan sertifikat hak komunal dalam bingkai hukum UUPA dan Peraturan Pemerintah Nomor 24 Tahun 1997 tentang Pendaftaran Tanah merupakan konsep hukum baru yang diharapkan dapat menjawab permasalahan dalam kepastian hukum penguasaan tanah adat oleh masyarakat hukum adat. Hukum adat di Bali menyebut tanah druwe desa yaitu tanah-tanah adat yang berkaitan dengan persekutuan hukum adat (Jayantiari, 2017). Tanah-tanah tersebut letaknya di desa adat Bali atau biasa disebut sebagai Desa Pakraman. Tanah druwe desa dikonsepsikan oleh pemerintah sebagai tanah komunal yang perlu juga untuk disertifikatkan guna memperoleh kepastian hukum dalam hal kepemilikannya.

Desa Pakraman telah ditetapkan sebagai desa adat yang berhak memiliki hak komunal atas tanah berdasarkan Keputusan Menteri Agraria dan Tata Ruang/Kepala Badan Pertanahan Nasional Nomor 276/KEP-19. 2/X/2017 tentang Penunjukan Desa Pakraman di Provinsi Bali sebagai subyek hak pemilikan bersama (komunal) atas tanah. Akan tetapi, pada implementasinya pemangku adat Desa Pakraman sebagai pihak yang berwenang dalam mendapatkan sertifikat hak komunal atas tanah sebagai perwakilan dari seluruh masyarakat desa masih belum mendapatkan sertifikat tersebut sebagai kepastian hukum dalam kepemilikan tanah.

Berdasarkan hasil penelusuran bersama masyarakat adat Desa Pakraman, ditemukan bahwa tanah pekarangan tidak disertifikat di desanya. Hal tersebut karena beberapa masyarakat adat di Bali berpandangan bahwa apabila tanah adatnya telah memiliki sertifikat, maka peluang tanahnya untuk beralih kepada pihak lain akan semakin besar. Hal ini tentu menjadi kendala bagi pemerintah dalam melaksanakan program pendaftaran tanah. Berdasarkan permasalahan tersebut, penulis tertarik untuk melakukan kajian yang berjudul "Implementasi Pendaftaran Hak atas Tanah Komunal Di Desa Pakraman Bungbungan, Kabupaten Jembrana Provinsi Bali (Studi Keputusan Menteri ATR/ BPN Nomor 276/ KEP-19. 2/X/2017)".

Kajian ini berbeda dengan kajian-kajian sebelumnya karena yang berusaha penulis lihat adalah pendaftaran tanah pekarangan desa yang memang baru diwajibkan semenjak tahun 2017. Hal 
ini merupakan kasus baru bagi masyarakat adat di Bali. Penting untuk dilihat lebih jauh tentang penerapan pendaftaran hak atas tanah komunal masyarakat hukum adat di Desa Adat Pakraman Bungbungan Kabupaten Jembrana, serta menelusuri hal-hal yang menghambat pendaftaran hak atas tanah komunal dan upaya yang dilakukan oleh pemerintah untuk mengatasi hambatan tersebut.

\section{METODE}

Pada artikel ini penulis menggunakan metode kajian hukum yuridis empiris yang mengkaji ketentuan hukum yang berlaku serta apa yang terjadi dalam kenyataannya dalam masyarakat (Arikunto, 2012). Adapun metode pendekatan untuk kajian ini menggunakan pendekatan yuridis sosiologis yang merupakan pendekatan dengan menganalisis tentang bagaimana reaksi dan interaksi yang terjadi ketika suatu sistem norma bekerja dalam masyarakat.

Lokasi kajian ini dilakukan di Desa Pakraman Bungbungan Desa Yehembang Kecamatan Mendoyo Kabupaten Jembrana Provinsi Bali dan di Kantor Pertanahan Kabupaten Jembrana. Populasi dalam kajian ini adalah perangkat desa yaitu Bendesa Adat dan perangkat desa serta sebelas kepala keluarga yang berada di lokasi kajian. Mereka semua merupakan satu kesatuan masyarakat hukum adat yang memiliki hak ulayat atau hak komunal atas tanah. Pengambilan sampel menggunakan metode purposive sampling yaitu pengambilan sampel yang berdasarkan atas suatu pertimbangan tertentu seperti sifat-sifat populasi ataupun ciriciri yang sudah diketahui sebelumnya.

Jenis data pada kajian ini terbagi atas tiga jenis, yaitu data primer, data sekunder, dan data tersier. Data primer dalam kajian ini berupa penjelasan dari Bendesa Adat, Kepala Desa/Perbekel Desa Yehembang, dan beberapa pejabat serta staf kantor pertanahan Kabupaten Jembrana sebagai responden. Data sekunder diperoleh dari bahan kepustakaan dengan cara menelusuri peraturan perundangundangan, dokumen-dokumen, artikel ilmiah, buku-buku, hasil kajian yang berwujud laporan, dan sebagainya. Data tersier yang digunakan oleh penulis sebagai data pendukung dalam kajian ini adalah Kamus Hukum dan Kamus Besar Bahasa Indonesia (KBBI). Analisis data sekunder dilakukan dengan menggunakan analisis asas-asas hukum dan perundang-undangan yang terkait dengan hambatan pendaftaran tanah komunal masyarakat hukum adat di Desa Pakraman Bungbungan Kabupaten Jembrana.

\section{HASIL DAN PEMBAHASAN}

\section{Implementasi Pendaftaran Hak Atas Tanah Komunal di Desa Adat Pakraman Bungbungan Kabupaten Jembrana Provinsi Bali}

Ketentuan dalam Pasal 3 UUPA berpangkal adanya pengakuan hak ulayat dalam hukum tanah nasional yang disertai dua syarat, yakni syarat eksistensi dan syarat pelaksanaan. Syarat eksistensi berarti hak ulayat masyarakat hukum adat tetap diakui apabila dalam kenyataannya masih ada. Syarat pelaksanaan berarti pelaksanaan hak ulayat tidak boleh bertentangan dengan hukum nasional yang berlaku. Pengakuan dan perlindungan hak ulayat yang diatur dalam UUPA tersebut mengandung pengertian bahwa secara yuridis pengakuan dan perlindungan hak ulayat berada dalam posisi yang lemah. Kewenangan yang dimiliki masyarakat hukum adat untuk mengatur penggunaan hak ulayatnya menjadi sangat terhimpit karena sistem di dalam pemerintahan Indonesia saat ini sulit untuk memberikan kemungkinan bagi masyarakat hukum adat untuk dapat mengambil perannya tersebut.

Adanya klausul dalam UUPA yang menyatakan bahwa pelaksanaan hak ulayat dibatasi oleh adanya kepentingan nasional dan negara juga sangat abstrak karena nantinya dapat ditafsirkan secara luas (Samosir, 2013). Selain itu, penyebutan "hak ulayat" dan "masyarakat hukum adat" dalam Pasal 2 ayat (4) dan Pasal 3 UUPA tidak jelas dan samar-samar, sehingga berimplikasi pada ketidakjelasan pada penjabaran serta kurangnya sosialisasi mengenai hak ulayat. Hal ini menjadikan pasal-pasal tersebut hanya menjadi pasal tidur saja.

Pemberian pengakuan dengan pembatasan tersebut yang menjadikan posisi dari hak ulayat tersebut menjadi lemah. Undang-Undang Pokok Agraria tidak menghapus hak ulayat, namun UUPA juga tidak akan mengaturnya secara rinci. Pengakuan terhadap hak ulayat tanpa adanya pengaturan mengenai hak tersebut akan menjadi suatu dilema tersendiri karena pengaturan hak ulayat dalam UUPA bukan pengaturan yang 
memberikan perlindungan dan kepastian hukum bagi masyarakat hukum adat sebagaimana tujuan dan hakekat dari suatu norma hukum (Harsono, 2008). Hal tersebut dikarenakan dapat menyebabkan langgengnya eksistensi dari hak ulayat tersebut.

Pada tahun 1999, Kementerian Agraria/Kepala Badan Pertanahan Nasional pernah mengeluarkan Peraturan Menteri Agaria Nomor 5 Tahun 1999 tentang Pedoman Penyelesaian Masalah Hak Ulayat Masyarakat Hukum Adat (selanjutnya disebut dengan Permen Agraria Nomor 5 Tahun 1999). Diberlakukannya aturan tersebut karena dipandang perlu adanya sosialisasi yang menyeluruh mengenai konsep dari tanah adat/tanah ulayat serta dilengkapi dengan peraturan perundang-undangan lainnya dan pemahaman dari pihak-pihak terkait sebagai pelaksana dari peraturan yang mengatur mengenai keberadaan tanah adat/tanah ulayat tersebut. Peraturan menteri ini telah mengatur mengenai eksistensi dan pengakuan Negara atas tanah ulayat masyarakat hukum adat. Dalam Pasal 5 ayat (2) Permen Agraria Nomor 5 Tahun 1999 disebutkan bahwa keberadaan tanah ulayat akan dinyatakan dalam sebuah peta dasar pendaftaran tanah.

Keberadaan tanah adat di Indonesia tersebar dari Sabang sampai Merauke dengan nama dan pola pengaturan berdasarkan tatanan hukum adat yang berlaku di daerah tersebut (Harsono, 2003). Hukum adat memiliki konsepsi komunalistik religius yang memungkinkan penguasaan tanah secara individual dan sekaligus mengandung unsur kebersamaan. Sifat komunalistik menunjukkan adanya hak bersama atas tanah dari para anggota masyarakat hukum adat yang selanjutnya dikenal dengan sebutan tanah ulayat atau tanah komunal. Tanah ulayat merupakan tanah kepunyaan bersama yang diwariskan secara turun-temurun oleh nenek moyang kepada masyarakat hukum adat, sebagai pendukung kehidupan dan penghidupan masyarakat tersebut sepanjang masa.

Hak komunal dan/atau hak ulayat harus dipahami sebagai hak milik yang harus digunakan secara tepat maka konsepsi hukum yang digunakan sepatutnya harus mengandung unsur-unsur kepentingan umum (Salam, 2016). Tanah ulayat juga diyakini sebagai alat untuk mempererat hubungan kekerabatan masyarakat hukum adat dan menunjukkan satuan wilayah yang dikuasainya.
Tanah adat di Bali dikenal dengan tanah druwe desa yang berada di bawah kekuasaan desa pakraman. Desa pakraman adalah istilah yang digunakan untuk menyebut lembaga sosial religius yang menaungi kesatuan masyarakat hukum adat yang ada pada tiap-tiap desa di Bali. Desa pakraman mempunyai hak otonomi bersumber dari hukum adat untuk mengatur rumah tangganya sendiri. Secara garis besar otonomi desa pakraman membuat aturan sendiri (awig-awig), melaksanakan sendiri peraturan yang dibuat (melalui prajuru), mengadili dan menyelesaikan sendiri suatu permasalahan (dalam lembaga kertha desa), dan melakukan pengamanan sendiri (melalui pekemitan, pegebagan, pecalangan).

Pengakuan tanah adat dapat juga dilihat pada Pasal 22 ayat (1) Ketentuan-Ketentuan Konversi UUPA. Dari ketentuan tersebut jelas menunjukkan bahwa pengakuan tanah adat di Indonesia, khususnya di Bali telah diakui dalam UUPA dengan istilah hak atas druwe desa dan dapat dikonversi menjadi hak milik sepanjang pemegang haknya memenuhi syarat sebagai subjek hukum yang dapat mempunyai hak milik atas tanah sebagaimana ditentukan dalam Pasal 21 UUPA. Ketentuan-Ketentuan Konversi UUPA juga secara tegas menetapkan tanah-tanah yang telah dikuasai rakyat secara adat diakui sebagai tanah hak milik adat, kecuali tanah yang sejak awal merupakan tanah komunal atau tanah-tanah untuk kepentingan tertentu. Berdasarkan ketentuan itu, tanah yang berstatus (bekas) hak milik adat dan tanah (bekas) hak Indonesia lainnya, penetapan haknya melalui prosedur konversi, baik penegasan konversi maupun melalui pengakuan hak dengan memenuhi asas publisitas, yaitu pengumuman guna memberikan kesempatan bagi orang lain yang merasa keberatan sesuai Peraturan Pemerintah Nomor 24 Tahun 1997 tentang Pendaftaran Tanah.

Adanya ketentuan konversi tersebut diharapkan membawa kabar baik dalam menjamin kepastian hukum terhadap pemilikan tanah adat oleh desa pakraman di Bali. Namun dalam praktiknya, ketentuan konversi tersebut rentan menimbulkan konflik atas pemilikan dan penguasaan tanah adat. Tanah adat di Bali merupakan tanah bersama yang dimiliki dan dikuasai oleh desa pakraman secara komunal. Sebagian tanah komunal ini penguasaannya diserahkan kepada anggota masyarakat desa 
pakraman (krama desa) sebagai tanah individual tidak penuh, yakni tanah Pekarangan Desa dan tanah Ayahan Desa. Namun yang menjadi kekhawatiran dari Ketentuan-Ketentuan Konversi UUPA tersebut adalah adanya konversi tanah Pekarangan Desa dan tanah Ayahan Desa menjadi tanah individual penuh, seperti kasus tanah Pekarangan Desa di Desa Pakraman Lemukih (Kabupaten Buleleng), kasus tanah Ayahan Desa di Desa Pakraman Culik (Kabupaten Karangasem), kasus tanah Pekarangan Desa di Desa Pakraman Kemenuh (Kabupaten Gianyar), kasus tanah Pekarangan Desa dan tanah Ayahan Desa di Desa Pakraman Tamanbali (Kabupaten Bangli), serta kasus tanah Pekarangan Desa dan tanah Ayahan Desa di Desa Pakraman Tusan (Kabupaten Klungkung) (Suwitra 2010). Jika tanah adat ini dikonversi menjadi tanah individual penuh (hak milik pribadi), maka akan dapat melemahkan bahkan menghilangkan eksistensi dari tanah druwe desa di Bali. Lamakelamaan tanah tersebut akan dapat dialihkan kepada orang luar (bukan krama desa pakraman) dan akan menghilangkan segala kewajiban yang melekat pada tanah tersebut.

Tanah druwe desa (arti luas) merupakan tanah milik desa pakraman yang terdiri dari tanah druwe desa (arti sempit), tanah pura, tanah pekarangan desa, dan tanah ayahan desa. Berdasarkan Ketentuan Konversi UUPA, nampak ada tiga subjek hak yang dapat melakukan permohonan konversi terhadap tanah druwe desa menjadi tanah milik, yaitu desa pakraman, lembaga pura, dan anggota masyarakat desa pakraman (krama desa). Tanah pura dapat diterbitkan sertifikat hak milik melalui permohonan konversi berdasarkan Surat Keputusan Menteri Dalam Negeri Nomor SK. 556/DJA/1986. Hal ini merujuk kepada Peraturan Pemerintah Nomor 38 Tahun 1963 tentang Penunjukan Badan-Badan Hukum Yang Dapat Mempunyai Hak Milik Atas Tanah, salah satunya adalah Badan Keagamaan (Sukarja 2009). Oleh karena itu, tanah pura yang dimiliki oleh desa pakraman sudah dapat disertifikatkan atas nama pura, karena sebelumnya ada yang disertifikatkan atas nama pribadi prajuru (pengurus) atau pemangku (petugas keagamaan) yang bertanggung jawab atas pura tersebut.

Berdasarkan ketentuan Pasal 1 Peraturan Pemerintah Nomor 38 Tahun 1963, desa pakraman tidak ditunjuk sebagai subjek hukum yang dapat mempunyai hak milik atas tanah. Hal ini mengakibatkan desa pakraman tidak dapat menyertifikatkan tanah druwe desa sebagai hak milik atas tanah yang terkuat dan terpenuh menurut hukum pertanahan yang berlaku. Atas dasar itulah merujuk pada ketentuan Peraturan Menteri Agraria dan Tata Ruang/Kepala Badan Pertanahan Nasional Nomor 10 Tahun 2016 tentang Tata Cara Penetapan Hak Komunal Atas Tanah Masyarakat Hukum Adat dan Masyarakat Yang Berada Dalam Kawasan Tertentu, Surat Gubernur Provinsi Bali Nomor 590/70/B. Tapem tentang Hasil Rapat Koordinasi Proses Pengusulan Desa Pakraman Sebagai Subjek Hak Milik Atas Tanah dan Surat Kepala Kantor Wilayah Badan Pertanahan Nasional Provinsi Bali Nomor 1329/8-51/IX/2017 tentang Usulan Penunjukan Pakraman sebagai Subjek Hak Milik Atas Tanah, diterbitkanlah Keputusan Menteri Agraria dan Tata Ruang/Kepala Badan Pertanahan Nasional Nomor 276/Kep-19.2/X/2017 tentang Penunjukan Desa Pakraman di Provinsi Bali Sebagai Subyek Hak Pemilikan Bersama (Komunal) Atas Tanah, sehingga tanah druwe desa dapat disertifikatkan atas nama desa pakraman.

Tanah druwe desa di Bali dapat dijabarkan dalam arti luas dan arti sempit. Menurut Dharmayuda tanah druwe desa dalam arti yang luas meliputi empat tanah (Sukarja, 2009). (a) tanah Druwe Desa (arti sempit) adalah tanah yang dimiliki atau dikuasai desa pakraman yang bisa didapat melalui usaha-usaha pembelian ataupun usaha lainnya, meliputi tanah pasar, tanah kuburan/setra, tanah lapangan dan tanah balai desa. (b) Tanah pura merupakan tanah-tanah yang dulunya milik desa yang khusus dipergunakan untuk keperluan pura. Tanah pura ini ada dua macam yaitu tanah yang khusus untuk tempat pembangunan pura (tanah Tegak Pura) dan tanah yang diperuntukan guna pembiayaan keperluan Pura (tanah Palaba Pura), misalnya untuk keperluan biaya rutin dan biaya perbaikan Pura. (c) Tanah pekarangan desa merupakan tanah yang dimiliki oleh desa pakraman yang diberikan kepada krama desa untuk tempat mendirikan perumahan dalam ukuran luas tertentu dan hampir sama untuk tiap keluarga. (d) tanah Ayahan Desa adalah tanah desa pakraman yang dipergunakan untuk pertanian dan penggarapannya 
diserahkan kepada masing-masing krama desa dengan hak untuk dinikmati dan kewajiban untuk memberikan ayahan kepada desa pakraman.

Diterbitkannya Keputusan Menteri Agraria dan Tata Ruang/Kepala Badan Pertanahan Nasional Nomor 276/Kep-19. 2/X/2017 diharapkan mampu menjamin kepastian hukum tanah druwe desa di Bali melalui penerbitan sertifikat tanah. Pada proses pelaksanaan pendaftaran hak atas tanah saat ini sudah menggunakan Pendaftaran Tanah Sistematis Lengkap (PTSL) untuk percepatan proses pendaftaran tanah sebagaimana dimaksud dalam pasal 19 UUPA, pemerintah melalui Kementerian Agraria dan Tata Ruang/Badan Pertanahan Nasional (Kementerian ATR/BPN).

Langkah yang dilakukan untuk mempercepat proses pendaftaran tanah melalui Participatory Land Registration (PaLaR) dalam program PTSL, melibatkan masyarakat secara aktif baik dalam pengumpulan data yuridis maupun data fisik. Dalam Peraturan Menteri Agraria dan Tata Ruang/ Kepala Badan Pertanahan Nasional Republik Indonesia Nomor 6 Tahun 2018 disebutkan bahwa data yuridis adalah informasi mengenai status penguasaan dari suatu bidang tanah dan satuan rumah susun, pemegang hak, pihak yang menguasai, dan hak serta beban lain yang melekat dalam satuan bidang tanah atau satuan rumah susun tersebut. Data fisik merupakan informasi yang mencakup letak, batas, dan luas dari bidang tanah dan satuan rumah susun, serta informasi mengenai bangunan atau bagian bangunan yang ada di atasnya.

Pendaftaran Tanah Sistematis Lengkap merupakan kegiatan pendaftaran tanah pertama kali dalam satu wilayah administrasi desa/kelurahan atau setingkat yang meliputi pengumpulan data fisik dan data yuridis. Kegiatan ini dilakukan serentak di seluruh wilayah Indonesia. Target nasional PTSL yang dicanangkan oleh pemerintah sebesar 8.394.000 bidang untuk target pengukuran dan 7.842 .317 bidang untuk target yuridis (Kementerian ATR/BPN, 2018). Di Provinsi Bali yang menjadi lokasi kajian, memperoleh target PTSL sebesar 270.000 bidang, baik untuk target pengukuran maupun yuridisnya. Kantor Pertanahan Kabupaten Jembrana memperoleh target 18.100 bidang.

Participatory Land Registration (PaLaR) pada dasarnya merupakan pendekatan dalam proses pendaftaran tanah melalui partisipasi aktif masyarakat dalam pengumpulan data yuridis maupun data fisik yang diperlukan untuk kelengkapan administrasi pertanahan. Menurut Asiama, et al. (2017) PaLaR meliputi empat aspek, yaitu: (a) pengaruh dari pemerintah dan para profesional (top-down); (b) kontribusi masyarakat; (c) inovasi teknologi; dan (d) kebutuhan masyarakat.

Dalam pelaksanaannya, PaLaR dapat dilakukan pada saat pelaksanaan pengumpulan data yuridis melalui partisipasi aktif masyarakat dalam pengisian formulir isian inventarisasi dan identifikasi peserta PTSL yang dapat dilakukan bersamaan dengan pengumpulan data fisik, yaitu pemetaan partisipatif masyarakat dalam rangka penyusunan peta kerja. Hasil dari pengumpulan data fisik adalah peta bidang tanah. Untuk memperoleh peta bidang tanah perlu dilakukan terlebih dahulu pengukuran dan pemetaan bidang tanah. Dalam rangka mempermudah kegiatan pengukuran dan pemetaan bidang tanah perlu disusun terlebih dahulu peta kerja. Peta kerja digunakan sebagai acuan atau pedoman untuk identifikasi, delineasi, dan pemetaan batas bidang tanah, baik yang sudah terdaftar maupun yang belum terdaftar. Pengumpulan informasi yang diperlukan dalam peta kerja seperti informasi mengenai letak, batas, dan luas bidang tanah yang akurat dapat dioptimalkan dengan pemetaan partisipatif. Masyarakat dianggap mengetahui dengan jelas keberadaan bidang tanah yang mereka miliki beserta batas di sekeliling bidang tanah tersebut. Selain itu, masyarakat diharapkan dapat membantu dalam pengumpulan informasi mengenai bidang tanah terdaftar dan belum terdaftar, sehingga dapat diketahui secara pasti obyek yang dapat diikutsertakan dalam program PTSL.

Berikut ini adalah tahapan pelaksanaan PTSL yang dibagi menjadi beberapa tahapan. Tahapan pertama ialah penyuluhan, yang dijadwalkan terlebih dahulu dan dilaksanakan oleh petugas BPN yang berada di wilayah desa atau kelurahan. Tahapan kedua ialah pendataan/pengumpulan data fisik dan yuridis. Setelah dilaksanakan penyuluhan, petugas akan melakukan pendataan kepada masyarakat dengan menanyakan status kepemilikan tanah, cara perolehan tanah tersebut, apakah dari warisan, hibah atau pun jual beli dan 
juga bukti setor Bea Perolehan Hak Atas Tanah dan Bangunan (BPHTB) dan Pajak Penghasilan (kecuali untuk masyarakat yang tidak mampu bebas biaya) yang sudah dibayarkan. Adapun persyaratan yang harus dilengkapi adalah fotokopi identitas diri (KTP, KK), surat pernyataan penguasaan fisik bidang tanah yang diketahui oleh dua orang saksi, riwayat tanah (jual beli, hibah atau warisan), fotokopi Letter C (SPPT), dan untuk permohonan tanah Desa Adat Pakraman dilengkapi dengan surat pernyataan dari desa adat bahwa tanah tersebut adalah tanah milik Desa Adat Pakraman dan diketahui oleh bendesa adat dan susunan pengurus desa adat yang ada di Desa Pakraman.

Tahapan keempat yakni pengukuran. Setelah melewati proses administrasi dan dikatakan lolos, selanjutnya petugas akan melakukan pengukuran. Pengukuran tersebut meliputi panjang dan lebarnya tanah yang dimiliki, batas tanah yang menjadi pembatas yang telah mendapat persetujuan dari pemilik tanah yang berbatasan, bentuk bidang, dan juga luas bidang tanahnya. Tahapan keempat adalah Sidang Panitia A. Sidang ini beranggotakan tiga orang BPN dan satu orang perwakilan dari desa atau kelurahan. Tujuan dari pengadaan sidang ini adalah untuk meneliti data yuridis, pemeriksaan lapangan, mencatat sanggahan, menarik kesimpulan, serta mendapatkan keterangan tambahan.

Tahapan kelima adalah pengumuman data fisik dan yuridis serta pengesahan. Maka panitia akan mengumumkan hasil, lalu petugas akan melakukan pengesahan kurang lebih 14 hari setelah pengumuman itu ditempel di kantor desa atau kantor kelurahan ataupun kantor pertanahan setempat. Apabila dalam jangka waktu 14 hari setelah pengumuman tersebut tidak ada sanggahan, artinya tanah yang didaftarkan aman bukan tanah sengketa, maka dapat dilanjutkan untuk penerbitan sertifikat. Pengumuman tersebut sekurang-kurangnya berisi nama pemilik tanah, luas tanah, letak tanah, dan bidang tanah.

Tahapan terakhir adalah penerbitan sertifikat oleh kementerian Agraria Tata Ruang/Badan Pertanahan Nasional yang menjadi bukti autentik seseorang atas kepemilikan tanah miliknya yang dibagikan langsung kepada pemilik tanah. Adapun biaya untuk program ini dibebankan kepada pemerintah atau dengan kata lain gratis (tidak dipungut biaya). Peserta PTSL hanya dibebankan untuk membayar penyediaan surat tanah untuk tanah yang belum memiliki surat tanah, pembuatan dan pemasangan tanda batas, Bea Perolehan Hak Atas Tanah dan Bangunan (BPHTB) jika terkena, dan lain-lain seperti materai, fotokopi Letter $\mathrm{C}$ ataupun biaya saksi. Hal ini sesuai dengan penelitian Riardo (2019) yang menjelaskan proses konversi hak atas tanah ulayat kaum menjadi hak milik melalui program PTSL dilakukan berdasarkan Peraturan Menteri Agraria dan Tata Ruang/Kepala Badan Pertanahan Nasional Republik Indonesia Nomor 12 Tahun 2017 tentang Percepatan Pendaftaran Tanah Sistematis Lengkap.

Prosedurnya yaitu lewat sosialisasi di awal, penyuluhan, pengumpulan data yuridis oleh satuan tugas yuridis, pengolahan dan pembuktian data, pemeriksaan tanah, pengumuman, penerbitan surat keputusan penetapan dan penegasan hak, pembukuan dan penyerahan sertifikat. Tanah ulayat kaum yang dikategorikan kluster 1 atau datanya lengkap dan tidak bermasalah dapat didaftarkan dengan bebas biaya serta rentang waktu yang cukup singkat. Penentuan Subyek Pemegang Hak Dalam Pembuatan Sertifikat Tanah Ulayat Kaum berkaitan dengan pembagian jenis harta di Minangkabau. Tanah ulayat kaum merupakan harta pusaka tinggi di Minangkabau, khususnya di Kota Solok sebagai lokasi penelitian. Dalam hal ini pemegang hak biasanya dipilih atas kesepakatan seluruh anggota kaum yang pada umumnya dipegang oleh Mamak Kepala Waris. Akan tetapi untuk nama pemegang sertifikat ini ada juga yang bukan Mamak Kepala Waris langsung, bisa anggota kaum lain yang dipercaya untuk mewakili, tentunya berdasarkan kesepakatan kaum tersebut. Akibat hukum konversi tanah ulayat kaum menjadi hak milik terhadap status ulayat kaum melalui program PTSL di Kota Solok status kepemilikannya tetap dianggap sebagai hak milik kaum.

\section{Hambatan dan Upaya Pemerintah untuk Mewujudkan Kepastian Hukum Atas Kepemilikan Hak Komunal Masyarakat Hukum Adat di Desa Pakraman Bungbungan Kabupaten Jembrana}

Tanah pekarangan desa adalah tanah milik desa yang diberikan kepada krama desa untuk tempat mendirikan perumahan yang lazimnya dalam ukuran luas tertentu dan hampir sama untuk 
setiap keluarga. Pengertian ini perlu ditambahkan dengan kalimat mempunyai kaitan dengan kewajiban ngayah desa. Krama (anggota) masyarakat desa yang menguasai pekarangan desa berkewajiban untuk melakukan ayahan desa. Biasanya desa yang memiliki pekarangan desa merupakan ayahan ngarep berdasarkan jumlah karang desa, artinya setiap satu pekarangan desa hanya diwajibkan satu orang pengayah ngarep. Krama jangkep atau setiap kepala keluarga (KK) yang lainnya berkedudukan sebagai pengayah pengele atau pengampel yang artinya warga tersebut ikut menempati pekarangan desa namun sebagai krama yang dinomorduakan.

Ketentuan tentang pengaturan ini diatur dalam awig-awig desa pakraman baik yang sudah dituliskan maupun yang belum dituliskan. Ngayah desa mengandung arti melakukan segala kewajiban yang berhubungan dengan desa pakraman, termasuk dalam kaitannya dengan melakukan segala kewajiban terhadap khayangan tiga (khayangan desa) (Suwitra, 2011). Jadi dengan demikian tanah adat Bali berkaitan erat dengan kewajiban-kewajiban keagamaan dalam hal ini Agama Hindu. Dalam Pasal 1 angka 6 Peraturan Daerah Provinsi Bali menentukan bahwa "krama desa/krama banjar pakraman data dan atau yang bendesa bertempat tinggal di wilayah desa/banjar pakraman atau ditempat lain yang menjadi warga desa pakraman/banjar pakraman." Pasal 1 angka 7 menentukan "Krama pengempon/pengemong adalah krama desa pakraman/krama banjar pakraman yang mempunyai ikatan lahir batin terhadap pemeliharaan, perawatan, dan pelaksanaan kegiatan-kegiatan upacara di khayangan tersebut". Uraian di atas sesuai dengan pendapat Wignuyodiputro (1983) yang menyatakan bahwa antara persekutuan, dengan tanah yang didudukinya mempunyai hubungan yang bersifat religio magis.

Berdasarkan data yang penulis peroleh dari 11 kuesioner yang disebar kepada masyarakat di desa Pakraman Bungbungan maka ditemukan adanya beberapa hambatan terkait dengan proses penyertifikatan tanah, yakni mereka khawatir bahwa nantinya tanah pekarangan desa dapat dialihkan kepada pihak lain atau dijual oleh pemilik sertifikat. Untuk menjawab permasalahan tersebut maka peneliti membuat dua variabel kajian yaitu hubungan masyarakat adat dengan tanah yang dikaji dari aspek agama dan hubungan masyarakat adat dengan tanah dikaji dari aspek hukum yang berlaku di daerah Bali.

Pendaftaran tanah pekarangan desa hanya melahirkan dua hak yaitu hak menempati dan hak menguasai tanah secara turun-temurun, tetapi tidak dapat dialihkan kepada orang lain. Untuk memperoleh kepemilikan tanah maka BPN melakukan pengukuran dengan cara berkoordinasi dengan masyarakat sekitar dan perangkat desa yang mengetahui riwayat tanah adat yang terdapat di desa Bungbungan. Batas penguasaan atas tanah pekarangan tidak ditentukan, namun rata-rata luas nya $800 \mathrm{~m}^{2}$. Ada beberapa hambatan baik bagi masyarakat maupun Kantor Pertanahan Kabupaten Jembrana.

Ada 10 hambatan yang datang dari masyarakat antara lain sebagai berikut. (a) Masih ada hubungan kekerabatan antar masyarakat yang mendiami Desa Adat Pakraman Bungbungan, sehingga masyarakat tidak ingin tanah tersebut nantinya dialihkan kepada pendatang. (b) Kurangnya pemahaman dari masyarakat terkait dengan proses pendaftaran tanah komunal melalui PTSL 2019. (c) Masyarakat khawatir bahwa tanah yang sudah disertifikat dapat digadaikan atau dijual pada pihak lain. (d) Belum ada kesepakatan di antara pemucuk desa adat dan masyarakat untuk mendaftarkan tanah pekarangan desa. (e) Masalah alat pembuktian pemilikan tanah. (f) Rendahnya kesadaran masyarakat untuk membayar pajak bumi dan bangunan karena mereka berpikir bahwa tanah yang mereka tempati milik desa adat pakraman. (g) Respon masyarakat yang kurang terutama pada bidang yang terindikasi $\mathrm{K} 1$, $\mathrm{K} 4$, dan pada pemasangan tanda batas, banyak yang belum dilaksanakan padahal sangat penting untuk mengurangi permasalahan terutama tentang sengketa batas. (h) Masih lemahnya peran aktif aparat desa merespon proyek strategis nasional dikarenakan banyaknya pekerjaan yang mereka lakukan. Pendampingan dan penunjukan batas tidak bisa setiap hari sehingga tidak efektif waktu. (i) Faktor vegetasi/medan yang masih rimbun dan pemohon tidak bersedia membersihkan lokasi sehingga menyulitkan dalam pengukuran walaupun dengan GPS RTK. (j) Pemilik bidang tanah yang tempat tinggalnya di luar desa, kecamatan atau di luar kabupaten. Hambatan-hambatan dari 
masyarakat ini sejalan dengan penelitian yang dilakukan oleh Djafaruddin (2013) di Kecamatan Taliabu Utara Kabupaten Kepulauan Sula yang menunjukkan bahwa hambatan yang berasal dari masyarakat dipengaruhi oleh faktor masyarakat yang tidak mengerti tata cara untuk mendaftarkan hak kepemilikan atas tanah agar mendapatkan sertifikat dan adanya anggapan dari masyarakat bahwa proses pengurusan sertifikat selalu sulit, berbelit-belit, dan membutuhkan biaya yang cukup mahal.

Adapun hambatan yang datang dari Kantor Pertanahan Kabupaten Jembrana ada enam antara lain sebagai berikut. (a) Belum tersedianya kerangka dasar teknis, peta dasar, terutama peta kadaster. (b) Sulit mengumpulkan warga dalam melakukan sosialisasi. (c) Kurangnya respon dari pemerintah kabupaten dalam memperlancar proses sertifikasi tanah. (d) Kurangnya sumber daya manusia, pada Kantor Pertanahan Kabupaten Jembrana Petugas Ukur hanya berjumlah 10 orang untuk target sebesar 18.100 bidang. (e) Aplikasi sering error sehingga memperlambat dalam proses pengolahan data fisik dan entry data yuridis. (f) Tata Kelola Arsip GS/SU/SUS dan GU yang kurang bagus sehingga menyulitkan dalam proses pencariannya. Hal ini sejalan dengan penelitian yang dilakukan oleh Djafaruddin (2013) di Kecamatan Taliabu Utara Kabupaten Kepulauan Sula bahwa terdapat hambatan dari aspek petugas yaitu keterbatasan sumber daya manusia yang ada pada Kantor Pertanahan Kabupaten Kepulauan Sula, baik tenaga administrasi maupun tenaga pengukuran. Adanya keterbatasan sarana dan prasarana seperti kendaraan operasional dan ruang tempat kerja serta ruang penyimpanan warkah. Banyaknya pekerjaan serta gangguan teknis dalam komputer. Tenaga koreksi (kendali mutu) hasil pengukuran terbatas karena struktural hanya dilaksanakan oleh Kasubi PPK dan Kasi Pengukuran dan Pendaftaran Tanah.

Dari beberapa hambatan tersebut ada delapan upaya yang dilakukan pemerintah antara lain sebagai berikut. Pertama, Kantor Pertanahan Kabupaten Jembrana melakukan sosialisasi terkait kebijakan pemerintah tentang Pendaftaran Tanah Sistematis Lengkap yang menyatakan bahwa seluruh bidangbidang tanah yang ada dan belum di daftar harus segera didaftarkan untuk proses sertifikasi tanah. Untuk Tanah Pekarangan Desa dapat didaftarkan setelah diterbitkannya Surat Keputusan Menteri ATR/BPN Nomor: 276/KEP-19. 2/X/2017. Kedua, Kantor Pertanahan Kabupaten Jembrana melakukan pendekatan kepada Bendesa Adat di Desa Adat Pakraman Bungbungan agar nantinya bendesa adat dapat memberikan pemahaman kepada masyarakat adat bahwa sertifikasi tanah alas haknya hanyalah hak untuk menguasai tanah dan mewarisi tanah tetapi tidak untuk digadaikan dan dijual karena kepemilikan atas tanah merupakan hak milik Desa Adat Pakraman Bungbungan. Jadi kemungkinan untuk menjual tanah dan menggadaikannya bukan proses yang mudah karena harus mendapat persetujuan bendesa adat dan seluruh masyarakat di Desa Adat Pakraman Bungbungan. Ketiga, pada awalnya masyarakat adat di Desa Adat Bungbungan belum membuat kesepakatan untuk mendaftarkan tanah miliknya, namun petugas pendataan dari Kantor Pertanahan Kabupaten Jembrana berusaha untuk mendekati para tokoh masyarakat dan bendesa adat untuk meyakinkan mereka bahwa sertifikasi ini penting sebagai alat bukti penguasaan atas tanah yang dikuasai/ditempati oleh masyarakat sehingga dapat memberikan kepastian hukum. Keempat, Kantor Pertanahan Kabupaten Jembrana melakukan pengukuran dan pemetaan tanah di Desa Adat Pakraman Bungbungan tujuannya adalah untuk mempermudah proses pendaftaran tanah dan identifikasi bidang tanah. Setelah pengukuran dilakukan maka masyarakat nantinya dapat melakukan pendaftaram tanah secara online. Kelima, membuat jadwal yang disepakati bersama dengan aparatur desa agar bisa melakukan pendampingan saat proses pengukuran. Keenam, meminta kepada aparat desa terkait untuk menghimbau warganya membantu membersihkan lokasi agar mempermudah petugas saat pengukuran. Ketujuh, terus berkoordinasi dengan Pusdatin untuk kelancaran aplikasi. Kedelapan, memperbaiki penyimpanan dan pengelolaan arsip baik GU/SU/ SUS maupun BT.

Keberadaan sertifikat hak komunal dalam bingkai hukum UUPA dan Peraturan Pemerintah Nomor 24 Tahun 1997 merupakan konsep hukum baru yang diharapkan dapat menyelesaikan permasalahan hukum penguasaan tanah adat. Meskipun demikian, dalam implementasinya masih ditemukan hambatan baik di masyarakat 
sebagai subyek hukum maupun pemerintah sebagai penyelenggara hukum. Upaya-upaya untuk menyelesaikan hambatan-hambatan tersebut juga masih terus dilakukan.

\section{SIMPULAN}

Pendaftaran hak atas tanah komunal di Desa Adat Pakraman Bungbungan Kabupaten Jembrana Provinsi Bali pasca diterbitkannya Keputusan Menteri ATR/BPN Nomor 276/Kep19. 2/X/2017 diimplementasikan melalui Program Strategis Pemerintah yaitu Pendaftaran Tanah Sistematis Lengkap (PTSL) 2019. Ada beberapa hambatan yang dialami oleh masyarakat antara lain tidak adanya kesadaran untuk mendaftarkan tanah komunal, ketidaktahuan tertkait prosedur pendaftaran melalui PTSL, dan lemahnya peran aparat desa. Adapun upaya yang dilakukan oleh pejabat Kantor Pertanahan Kabupaten Jembrana ialah melakukan sosialisasi kepada masyarakat adat terkait hak yang lahir akibat pensertifikatan tanah tersebut, yaitu hak menguasai dan hak menempati serta prosedur pendaftaran melalui PTSL.

\section{DAFTAR RUJUKAN}

Arikunto, S. (2002). Prosedur Kajian Suatu Pendekatan Praktik. Jakarta: Rineka Cipta. Azzahra, F. (2019). Status Hak Atas Tanah Penduduk Desa dalam Kawasan Hutan Perum Perhutani. Jurnal Ilmiah Pendidikan Pancasila dan Kewarganegaraan, 4(1), 48-60.

Djafarudddin, T. (2013). Pelaksanaan Pendaftaran Tanah di Kecamatan Taliabu Utara Kabupaten Kepulauan Sula. Jurnal Lex Privatum, 1(1), 70-71.

Jayantiari, I. G. A. M. R. (2017). Eksistensi Tanah Adat di Bali dan Problematika Hukum dalam Pengembangan Investasi. Jurnal Ilmiah
Fakultas Hukum Universitas Udayana, 39(2). 108-119.

Harsono, B. (2008). Hukum Agraria Indonesia Sejarah Pembentukan Undang-Undang Pokok Agraria. Jakarta: Djambatan.

Muhammad, N., Agustian, R. A., \& Safultra, R. D. (2018). Kepastian Hukum Bagi Para Pemegang Surat Tanda Bukti Atas Tanah Berupa Sertifikat Hak Milik Ditinjau dari Hukum Agraria. Jurnal Hukum Progresif, 12(1), 2028-2047.

Riardo, R. (2019).Konversi Hak Atas Tanah Ulayat Kaum Menjadi Hak Milik Melalui Program Pendaftaran Tanah Sistimatis Lengkap di Kota Solok. Soumatera Law Review, 2(2), 193-206.

Salam, S. (2014). Kepastian Hukum Penerbitan Sertifikat Hak Komunal sebagai Pelaksanaan Reforma Agraria. Jurnal Cita Hukum, 4(2), $1-20$.

Samosir, D. (2013). Hukum Adat Eksistensi dalam Dinamika Perkembangan Hukum di Indonesia. Bandung: Nuansa Aulia.

Sinaga, P. (2014). Sertifikat Hak Atas Tanah dan Implikasi terhadap Kepastian Kepemilikan Tanah. Lex et Societatis, 2(7), 56-58.

Soedjono. (2008). Prosedur Pendaftaran Tanah. Jakarta: Rineka Cipta.

Suwitra, I. M. (2011). Larangan Untuk Pemindahan Tanah dalam Masyarakat Hukum Adat Bali: Perspektif Hukum Nasional. Jurnal Hukum dan Pembangunan, 41(1), 48-66.

Sudantra, I. K. (2018). Implikasi Keputusan Menteri ATR/Kepala BPN Nomor 276/KEP19.2/X/2017 Terhadap Kedudukan Tanah Milik Desa Pakraman. Jurnal Magister Hukum Udayana, 7(4), 546-564. 